\title{
KEKUATAN DAN TANTANGAN PENGAJARAN KRISTEN TENTANG PERNIKAHAN DALAM PERSPEKTIF JEMAAT GMAHK PUTRA AGUNG SURABAYA
}

\author{
Daniel Siswanto, Rudolf Sagala, Stimson Hutagalung \\ Program Pascasarjana Magister Filsafat Universitas Advent Indonesia \\ dansis33@yahoo.co.id
}

\begin{abstract}
This study aims to explore the congregation's understanding of the concept of marriage and to see the potential for divorce. The method used is a survey using a questionnaire. The research subjects were the Seventh-day Adventist Church, Putra Agung Congregation Jl. Karang Asem IV No. 6 Surabaya. The selected respondents were adult congregations, totaling 177 people. The sampling technique used was a quota sampling of $50 \%$ of the total number of adult congregations. The data were analyzed by making claims on the tendency of respondents' answers. The results show that the congregation's understanding of marriage is in accordance with Christian teachings which highly respect marriage and reject divorce. However, the potential for divorce is still there as seen from the small number of respondents who do not dare to ensure that they will not divorce if there are problems in the household.
\end{abstract}

Keywords : Christian Marriage Teaching, Divorce Prohibition, Divorce Potential

\begin{abstract}
Abstrak. Penelitian ini bertujuan menggali pemahaman jemaat tentang konsep pernikahan serta melihat potensi terjadinya perceraian. Metode yang digunakan adalah survey dengan menggunakan kuesioner. Subyek penelitian adalah jemaat Gereja Masehi Advent Hari Ketujuh Jemaat Putra Agung JI. Karang asem IV No 6 Surabaya. Responden yang dipilih adalah jemaat usia dewasa yang berjumlah 177 orang. Teknik pemilihan sampel menggunakan sampling kuota sebesar $50 \%$ dari total jumlah jemaat dewasa. Data dianalisa dengan membuat klaim terhadap kecenderungan jawaban responden. Hasil penelitian menunjukkan bahwa pemahaman jemaat mengenai pernikahan sesuai dengan ajaran Kristen yang sangat menghormati pernikahan dan menolak perceraian. Namun demikian, ada potensi perceraian yang terlihat dari adanya sebagian kecil responden yang tidak berani memastikan tidak akan melakukan perceraian jika ada masalah dalam rumah tangga.
\end{abstract}

Kata Kunci: Ajaran Pernikahan Kristen, Larangan Perceraian, Potensi Perceraian

Pernikahan adalah sebuah ikatan atau janji suci antara seorang laki-laki dan perempuan yang dilandasi rasa saling mencintai satu sama lain, tanpa adanya sebuah paksaan di antara kedua belah pihak (Musyafah, 2020). Berdasarkan pengertian tersebut berarti dua insan yang menikah memiliki satu perasaan yang sama, yang didasari dan 
dipenuhi dengan kecocokan satu sama lain dan tentunya memiliki pandangan dan visi yang sama menuju satu tujuan yang sama sehingga sebuah ikatan itu terjadi.

Bagi bangsa Yahudi keluarga merupakan sebuah tempat di mana identitas keagamaan dan kebangsaan dipelihara. Mereka mengakui bahwa dengan perkawinan, seseorang memperoleh jaminan perlindungan, kehidupan, kesejahteraan dan keselamatan (Jata, 2019).

Namun tidak dapat dipungkiri bahwa banyak pasangan yang menghadapi masalah dalam pernikahan mereka. Suryaningrum mengutip data Badan Peradilan Agama (Badilag) Mahkamah Agung RI tahun 2010 yang melansir bahwa rata-rata satu dari 10 pasangan menikah berakhir dengan perceraian di pengadilan selama tahun 2005 hingga 2010 (Suryaningrum, 2019). Meskipun sulit mendapatkan data mengenai angka perceraian di kalangan umat Kristen, namun patut diduga bahwa dari jumlah tersebut terdapat orang Kristen.

Apakah pasangan suami isteri Kristen boleh bercerai? Jawaban pertama pasti “tidak boleh". Gereja pada umumnya melarang dilakukannya perceraian. Dasar larangan ini terutama adalah Firman Tuhan yang terdapat dalam Matius 19:6 dan Markus 10:9, "apa yang telah dipersatukan Allah, tidak boleh diceraikan manusia."

Namun dalam hubungannya dengan pernikahan kembali, Maiaweng mengidentifikasi adanya tiga pendapat yang umum di kalangan umat Kristen. Pertama, menyetujui perceraian dan pernikahan kembali; 
kedua, menyetujui perceraian, tetapi tidak menyetujui pernikahan kembali; ketiga, tidak menyetujui perceraian dan pernikahan kembali (Maiaweng, 2017). Dari sini nampak bahwa ada sebagian orang Kristen yang menyetujui perceraian. Tampaknya ini sejalan dengan fakta bahwa tidak sedikit pasangan Kristen yang mengakhiri pernikahan melalui perceraian di pengadilan.

Banyak faktor yang mengakibatkan terjadinya perceraian. Seperti dikatakan Harisantoso, keputusan perceraian dibuat, biasanya setelah terjadi perseteruan yang sangat panjang (Harisantoso, 2019). Perceraian dapat bermula dari macetnya komunikasi antara suami isteri. Bila komunikasi tersebut tidak segera diperbaiki akan mengakibatkan masalahmasalah lain seperti ketidakpercayaan, kebencian, bahkan perselingkuhan (Gunawan, 2015) yang membawa hubungan pernikahan berujung pada perceraian.

Tampaknya menarik pendapat yang dikemukakan Matondang bahwa salah satu faktor penyebab terjadinya perceraian adalah karena kurangnya pemahaman agama di dalam keluarga. Agama memberikan pedoman nilai yang membentuk tingkah laku dalam mengarahkan pasangan dalam membina rumah tangga (Matondang, 2014). Pertanyaannya, apakah cukup banyaknya kasus perceraian di kalangan umat Kristen disebabkan juga karena kurangnya pemahaman umat mengenai ajaran Kristen, khususnya ajaran mengenai pernikahan dan perceraian? Penelitian ini dilakukan untuk menjawab pertanyaan tersebut. 
Penulis memilih jemaat Gereja Masehi Advent Hari Ketujuh Jemaat Putra Agung Jl. Karang asem IV No 6 Surabaya. Di jemaat ini kasus perceraian masih jarang terjadi. Dalam rentang waktu sepuluh tahun terakhir rata-rata hanya satu kasus per tahun.

Penelitian ini akan memberikan gambaran mengenai dua kemungkinan: Pertama, pengaruh pemahaman jemaat tentang pernikahan terhadap rendahnya angka perceraian. Kedua, memberikan perkiraan mengenai potensi perceraian di kalangan jemaat di masa mendatang.

\section{METODE}

Metode yang digunakan dalam penelitian ini adalah metode survey. Penelitian survey, seperti digambarkan Adiyanta, adalah penelitian yang mengambil sampel dari satu populasi dan menggunakan kuesioner sebagai alat pengumpulan data yang pokok. Sebab itu survey akan menghasilkan informasi yang bersifat statistik. Melalui survey, peneliti akan menanyakan kepada sejumlah responden tentang kepercayaannya, pendapat-pendapat, karakteristik, dan perilaku yang telah atau sedang terjadi (Adiyanta, 2019). Dengan metode survey, peneliti akan mengajukan pertanyaan mengenai pendapat para responden mengenai pernikahan yang merupakan ajaran dalam agama Kristen.

Kuesioner dibuat menggunakan Google Formulir dan dikirimkan kepada calon responden melalui aplikasi whatsapp. Dari jawaban yang 
masuk peneliti akan membuat claim tentang kecenderungan yang ada dalam populasi.

Sampel penelitian diambil dengan teknik sampling kuota, yaitu "menentukan sampel dari populasi yang mempunyai ciri-ciri tertentu sampai jumlah (kuota) yang diinginkan" (Sugiyono, 2013, p. 85). Jumlah jemaat dewasa Gereja Masehi Advent Hari Ketujuh Jemaat Putra Agung Jl. Karang asem IV No 6 Surabaya adalah 171 orang. Peneliti menetapkan kuota $50 \%$ dari jumlah populasi yaitu 86 orang. Kuesioner dikirim kepada seluruh anggota jemaat. Bila jawaban yang masuk sudah mencapai 86 maka penerimaan jawaban akan ditutup.

\section{HASIL}

\section{Profil Responden}

Dari hasil pengiriman link kuesioner ternyata ada 89 yang memberikan jawaban, lebih 3 orang, namun tetap diterima karena selisihnya kecil.

Gambar 1. Jenis Kelamin Responden

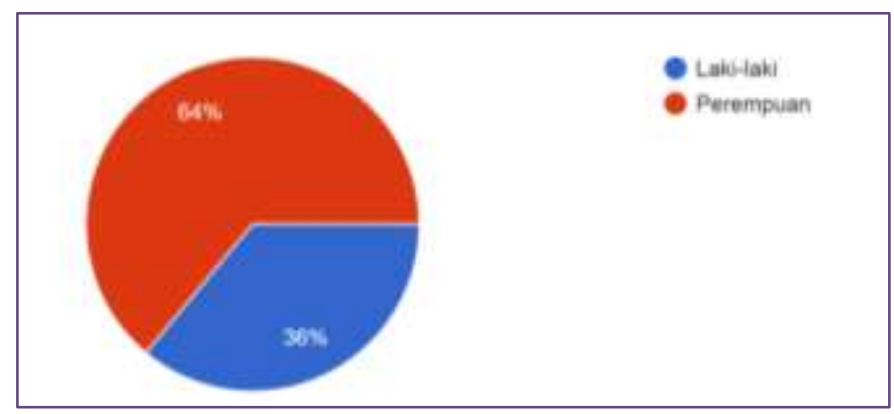


Responden yang mengisi angket survey menyatakan $64 \%$ perempuan dan $36 \%$ laki-laki.Jadi, responden yang mengisi angket yang telah disebarkan lebih banyak perempuan daripada laki-laki.

Gambar 2. Usia Responden

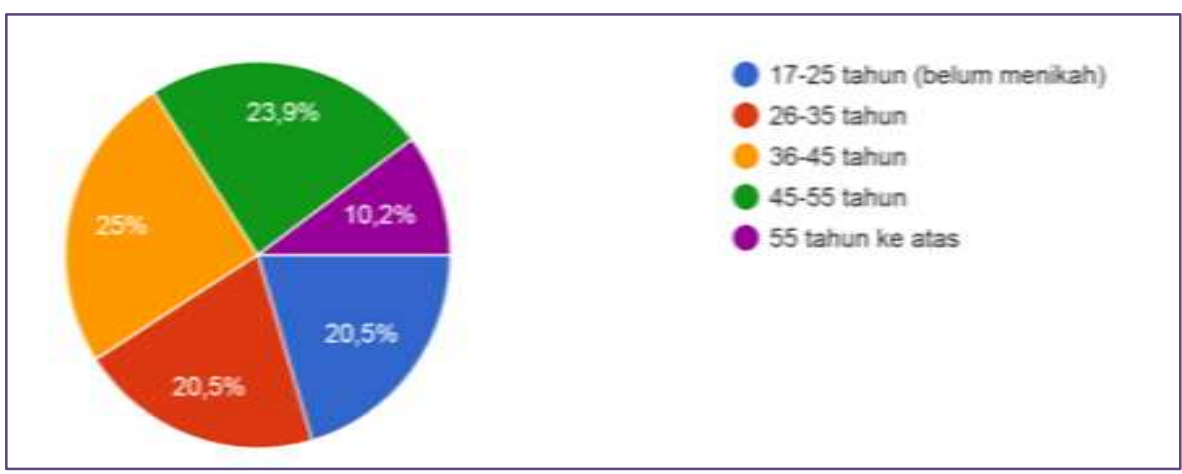

Data yang diperoleh mengenai usia responden yang dibagi menjadi lima klasifikasi di dapati bahwa: usia 17-25 tahun sebesar 20.5\%, usia 2635 tahun sebesar $20.5 \%$, usia $36-45$ tahun sebesar $25 \%$, usia $45-55$ tahun sebesar $23.9 \%$ dan usia 55 tahun keatas sebesar 10.2\%. Dengan demikian dapat dilihat bahwa pengisi angket survey ini paling banyak usia antara 36-45 tahun. Ini artinya responden yang mengisi angket ini paling banyak adalah pasangan-pasangan usia muda.

\section{Pandangan Responden tentang Pernikahan Sejalan dengan Ajaran Kristen}

Ada empat pernyataan yang diajukan kepada responden untuk menguji kesesuaian pandangan mereka tentang pernikahan dengan ajaran Kristen yaitu: 1) pernikahan adalah komitmen seumur hidup, 2) sesungguhnya Tuhan tidak pernah mengizinkan perceraian, 3) perceraian karena perzinaan diizinkan karena ketegaran hati manusia, 4) pernikahan 
adalah institusi yang suci. Pilihan jawaban yang disediakan adalah Sangat Setuju (SS), Netral (N), dan Tidak Setuju (TS).

Hasilnya menunjukkan bahwa pillihan jawaban responden sangat dominan pada pilihan Sangat Setuju. Perbedaan signifikan ada pada pertanyaan nomor 3, distribusi jawaban dominan hampir seimbang pada jawaban Sangat Setuju dan Netral. Pilihan Tidak Setuju juga lumayan besar. Berikut gambarannya:

Tabel 1. Pandangan tentang Pernikahan dan Perceraian

\begin{tabular}{|l|l|c|c|c|}
\hline \multirow{2}{*}{ No. } & \multicolumn{1}{|c|}{ Pertanyaan } & \multicolumn{3}{|c|}{ Jawaban (\%) } \\
\cline { 3 - 5 } & \multicolumn{1}{|c|}{ SS } & $\mathrm{N}$ & $\mathrm{TS}$ \\
\hline 1. & Pernikahan adalah komitmen seumur hidup & 95.5 & 0 & 4.5 \\
\hline 2. & $\begin{array}{l}\text { Sesungguhnya Tuhan tidak pernah mengizinkan } \\
\text { perceraian }\end{array}$ & 95.5 & 0 & 4.5 \\
\hline 3. & $\begin{array}{l}\text { Perceraian karena perzinaan diizinkan karena } \\
\text { ketegaran hati manusia }\end{array}$ & 47,2 & 34,8 & 18 \\
\hline 4. & Pernikahan adalah institusi yang suci & 97,8 & 2,2 & 0 \\
\hline
\end{tabular}

Tabel ini menggambarkan bahwa pandangan responden mengenai pernikahan dan perceraian masih sejalan dengan ajaran Kristen mengenai hal tersebut. Perbedaan jawaban yang agak signifikan pada pernyataan bahwa "perceraian karena perzinahan diizinkan karena ketegaran hati manusia" tampaknya merupakan ekspresi dari ketidaksetujuan responden terhadap perceraian.

\section{Peluang Terjadinya Perceraian}

Apakah dengan pandangan yang sejalan dengan ajaran Kristen yang sangat menjunjung tinggi pernikahan dan menolak perceraian, tidak ada peluang terjadinya perceraian di kalangan responden? Ternyata untuk 
pernyataan "Seandainya ada masalah dalam rumah tangga, saya tidak akan bercerai", 79,8\% menjawab Sangat Setuju dan 20,2\% memilih Netral.

Gambar 3. Pendapat terhadap pernyataan

"Seandainya ada masalah dalam rumah tangga, saya tidak akan bercerai"

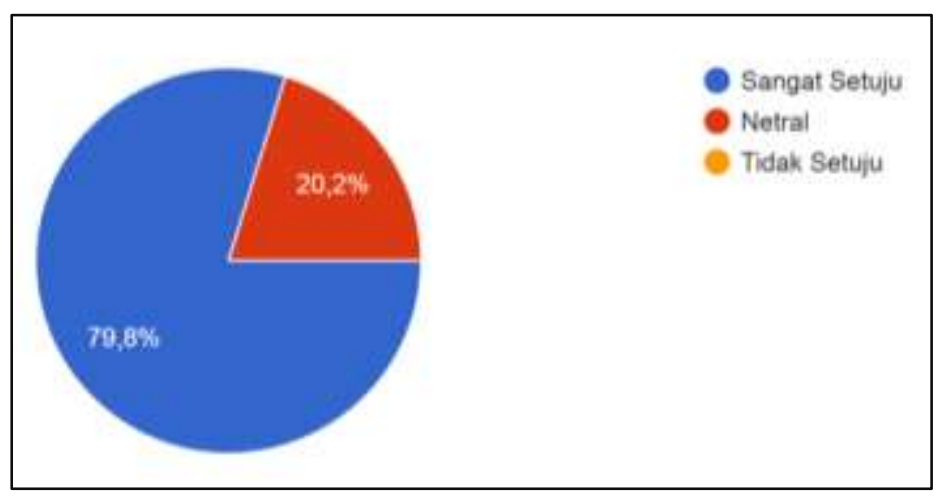

Hal ini menunjukkan bahwa meskipun sebagian besar sangat setuju, tetapi ada 20,2\% yang tidak berani memastikan bahwa mereka tidak akan bercerai jika ada masalah dalam rumah tangga. Artinya, meskipun kecil namun peluang terjadinya perceraian di kalangan responden tetap ada.

\section{PEMBAHASAN}

\section{Penerimaan terhadap Ajaran Mengenai Pernikahan}

Dari paparan hasil penelitian tampak bahwa responden sangat menghormati institusi pernikahan. Ini menunjukkan bahwa internalisasi gereja tentang makna pernikahan cukup berhasil. Suryani, seorang penulis Muslim, mengakui bahwa konsep sakralitas pernikahan dalam ajaran Kristen cukup mampu mengendalikan angka perceraian di kalangan Kristen (Suryani, 2018). Ini sejalan dengan fakta sangat 
rendahnya angka perceraian di Jemaat Gereja Masehi Advent Hari Ketujuh Jemaat Putra Agung Surabaya, tempat penelitian ini dilakukan.

\section{Allah Menghendaki Pernikahan Sebagai Komitmen Seumur Hidup}

Dalam Matius 19:6 dikatakan, "Demikianlah mereka bukan lagi dua, melainkan satu.Karena itu, apa yang telah dipersatukan Allah, tidak boleh diceraikan manusia" (Matius 19:6). Ini berarti sesungguhnya tidak ada alasan yang dapat dibenarkan untuk dilakukannya pemutusan pernikahan.

Dalam Perjanjian Lama, Allah menetapkan beberapa hukum untuk melindungi hak-hak dari orang yang bercerai, khususnya bagi perempuan seperti tertuang dalam Ulangan 24:1-4. Namun Yesus menekankan bahwa hukum-hukum ini diberikan karena ketegaran hati manusia, bukan karena rencana Allah (Matius 19:8).

Yesus sangat menaruh perhatian terhadap perceraian. PernyataanNya dapat ditemukan dalam Matius 5 dan 19, Markus 10, dan Lukas 16. Dalam Matius 19:3-9, Kristus mengajarkan dengan jelas bahwa perceraian adalah sebuah kompromi atas dosa manusia yang melanggar tujuan semula Allah bagi kesatuan intim dan permanen dari suatu ikatan pernikahan (Hutagalung et al., 2021).

Pada Khotbah Yesus di atas bukit yang tercatat dalam kitab Matius 5:31,32 lebih dulu membahas tentang perceraian. Menurut Matius 19 dan Markus 10 orang Farisi memaksa Yesus untuk membahas topik itu, dan Yesus menjawab persoalan itu dengan sangat jelas. Namun demikian, 
jawaban yang Tuhan Yesus berikan dalam Matius 19:9 seolah-olah membolehkan dan membenarkan perceraian dengan persyaratan khusus yaitu perzinaan (Surbakti, 2020). Namun Yesus secara implisit tidak membenarkan seorang suami menceraikan istrinya yang berzinah (Putra, 2020)

Perceraian di zaman Yesus dianggap biasa, meskipun hal ini bertentangan dengan ajaran Yesus dalam Alkitab yang sangat jelas mengenai lamanya pernikahan, yaitu merupakan komitmen seumur hidup, sampai kematian memisahkan (Stevanus, 2018). Namun pandangan yang umum tentang perceraian pada saat itu dipengaruhi oleh dua kelompok sekolah rabi-rabi yaitu Shammai dan Hillel. Kelompok Shammai menekankan perceraian terbatas pada kasus-kasus amoralitas seksual, sementara kelompok Hillel mengizinkan perceraian karena "alasan apa pun". Suku Shammaites membalik urutan kata-katanya dan memahaminya sebagai "masalah ketidaksenonohan", yang mereka pahami sebagai perzinaan atau khususnya dosa seksual. Orang Hillel memahami dua kata yang mencerminkan dua alasan terpisah untuk perceraian, "ketidaksenonohan" dan "masalah", dan karena "masalah" bisa merujuk pada apa saja, ini menjadi dasar untuk perceraian "sebab apa pun" (Putra, 2020).

Dalam Matius 19:6 menyatakan dengan tegas bahwa "apa yang telah dipersatukan oleh Allah, tidak boleh diceraikan manusia”. Dari pernyataan-Nya, Yesus dengan tegas menolak pandangan Hillel maupun 
Shammai. Kristus tidak mendukung perceraian bentuk apa pun (Rusli, 2019). Perceraian merusak hubungan antara suami dan istri, antara orang tua dengan anak-anak dan antara keluarga dengan masyarakat. Dengan kondisi yang demikian Yesus menegaskan tidak ada perceraian (Burton, 1907).

\section{Perceraian "Diizinkan” Karena Ketegaran Hati Manusia}

Perceraian telah menjadi kebiasaan bahkan di antara orang Israel seperti tergambar dalam Ulangan 24: 1-4. Perhatian utama dari hukum ini adalah untuk mencegah perceraian yang terburu-buru dan mencegah pernikahan kembali setelah perceraian. Ulangan 24:1 mengacu kepada kelakuan yang memalukan atau amoral yang belum separah perzinaan; tidak bisa menunjuk kepada perzinaan, karena perzinaan dihukum mati, bukan perceraian (bd. UI 22:13-22). Bagian ini hanya menunjukkan suatu praktek yang telah ada di Israel dan tidak menyarankan bahwa seorang laki-laki menceraikan istrinya tanpa alasan yang kuat. Musa tidak memerintahkan perceraian tapi hanya mengatur praktik hidup yang ada dalam bentuk hukum (Douglas, 1996).

Pada zaman Musa dan sepanjang era Perjanjian Lama, seorang pria menjadi tuan dari wanita yang dinikahinya. Pandangan ini umum dalam semua budaya pada masa itu, bahkan di antara orang Israel. Istri adalah milik suami dengan cara yang mirip dengan hartanya, hewan, dan budaknya (Keluaran 20:17). Hukum Yahudi tidak mengizinkan seorang 
wanita untuk memulai perceraian. Dia bisa menikah lagi hanya jika diberi akta cerai. Setiap janji yang dia buat dapat ditolak oleh suaminya (Bil. 30: 4-16). Suami bisa saja merajam pengantin wanita jika pada malam pernikahan dia mengetahui bahwa istrinya tidak perawan (UI. 22: 13-21).

Perceraian pada zaman para nabi bukanlah persoalan yang terlalu rumit. Sejauh seseorang, umumnya suami, menyatakan bahwa dirinya sudah bukan suami dari pasangannya lagi, maka perceraian sudah terjadi. Mungkin karena kemudahan tersebut, tingkat perceraian di masa itu cukup tinggi (Dias et al., 2020).

Di satu sisi, dalam kehidupan dan adat budaya orang Israel kuno, seorang istri yang ditinggalkan oleh suaminya tidak memiliki sarana yang dapat melindungi dirinya, bukan hanya itu saja, bahkan pria lain tidak diizinkan untuk menikah dengannya. Paling tidak, dengan surat cerai, seorang perempuan yang telah diceraikan memiliki jaminan perlindungan, minimal untuk mengklarifikasi statusnya sebagai wanita yang telah bercerai dengan suaminya, dengan demikian ia diperbolehkan untuk menikah dengan laki-laki lain (Maiaweng, 2017).

Ulangan 24:1-4, berfungsi untuk melindungi hak-hak perempuan perihal martabat dan harga diri mereka, terutama dalam keadaan di mana mereka tampak tidak berdaya oleh karena kekerasan hati pria (Davidson, 2011). Namun, ajaran Kristus di sini memperjelas bahwa ketentuan hukum Musa sehubungan dengan perceraian sangat tidak berlaku bagi orang Kristen, Hukum Kejadian 1:27; 2:24 mendahului hukum Ulangan 24:1-4. 
Tuhan tidak pernah mencabut hukum pernikahan yang Dia nyatakan sejak semula (Muller, n.d.).

Dalam rencana Allah yang sempurna perceraian tidak dibenarkan. Yesus berkata "karena ketegaran hatimu Musa mengizinkan kamu menceraikan istrimu, tetapi sejak semula tidaklah demikian”. (Matius 19:8). Yesus tidak mempersalahkan Musa tetapi menyalahkan orang-orang Israel yang tegar hati (Sirait, 2020). Keluaran 32:7-10 ketegaran menunjuk kepada sikap menduakan Tuhan dan upahnya adalah kebinasaan (Bdg. Ul. 9:13-14), sedangkan dalam Keluaran 33:3 ketegaran membuat Allah tidak menyertai umat Israel. Sementara Roma 9:18 menyatakan ketegaran hati menunjuk kepada sikap Firaun yang mengeraskan hati.

Perceraian adalah akibat langsung dari kekerasan hati manusia, tetapi sejak semula, perceraian tidak pernah menjadi bagian dari rencana Tuhan. Allah menyamakan pernikahan dengan hubungan antara Kristus dan gereja (Efesus 5:32), suatu persatuan yang dibangun di atas kasih setia yang tiada akhir untuk selama-lamanya. Itulah kesempurnaan Tuhan. Tapi, sejak kejatuhan umat manusia, ada banyak hal yang "sejak awal tidak begitu" (Coy, 2003).

Dalam Matius 19: 8, Yesus mengoreksi orang Farisi bahwa Musa tidak memerintahkan perceraian, tetapi memberikan izin perceraian

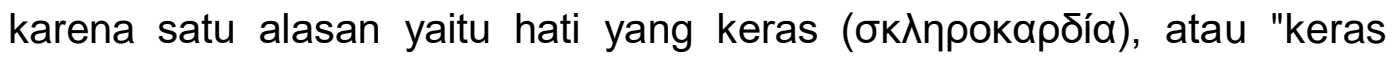
kepala" (Lodewyck, 2019, p. 158). 
Tuhan menciptakan manusia dengan kelembutan dan cinta kasih, perintah Tuhan adalah saling mengasihi, dengan sesama, dan terutama dengan pasangan kita (Matius 5:43; Efesus 5:25). Ketika hati kita berhenti memberi dan menerima cinta, hati kita menjadi keras (Andersen, 2019).

Fakta bahwa perceraian dikabulkan tidak menentukan bahwa orang yang menceraikan pasangan yang bersalah melakukan dosa, melainkan bukti bahwa dosa telah terjadi dan menghancurkan pernikahan.Tuhan tidak menginginkan perceraian, itu adalah bukti dosa dan kekerasan hati atau "penolakan untuk taat" (Roos, 2006). Kekerasan hati berarti tidak memaafkan pasangan, mencari celah untuk kemungkinan keluar dari pernikahan yang sah dan menyingkirkan pasangan. Pengampunan tidak dilakukan dan dipertimbangkan (Muller, n.d.).

Ketegaran hati yang Yesus kutip dalam Matius 19:8 memiliki pesan sangat penting, karena mengandung kebenaran mendasar tentang pernikahan. Tuhan sejak awal merancang pernikahan dengan perintah tidak ada perceraian. Karena ketegaran hati manusia maka di dalam kitab Ulangan perceraian diizinkan. Kalimat ini menunjukkan bahwa keadaan dunia tidak lagi seideal keadaan saat perkawinan pertama itu dibentuk oleh Tuhan. Dosa merusak kehidupan manusia, termasuk merusak nilai-nilai pernikahan yang sangat mulia yang telah Tuhan tetapkan (Sirait, 2020). 


\section{Potensi Perceraian di Kalangan Umat Kristen}

Seperti diidentifikasi Maiaweng (2017) bahwa di kalangan umat Kristen ada yang menyetujui dilakukannya perceraian. Tampak juga dalam hasil penelitian, meskipun sebagian besar responden memiliki pendapat yang sejalan dengan ajaran Kristen mengenai pernikahan, tetapi ada sebagian kecil yang tidak berani memastikan bahwa jika ada masalah dalam rumah tangga mereka tidak akan melakukan perceraian.

Dengan demikian potensi terjadinya perceraian di kalangan umat Kristen tetap ada. Faktanya juga tidak sedikit pernikahan Kristen yang sudah berakhir dengan perceraian. Jika demikian, sejaumana ajaran Kristen yang melarang perceraian akan bisa bertahan di masa depan?

Salah satu tantangan yang dihadapi datang dari gerakan perempuan menuntut keadilan dalam kehidupan rumah tangga. Data menunjukkan bahwa Kekerasan Dalam Rumah Tangga (KDRT) merupakan salah satu alasan dominan dalam gugatan cerai di pengadilan. Komnas Perempuan melansir Catatan Tahunan 2020 yang mengutip data dari Pengadilan Agama menunjukkan alasan perceraian terbesar ada empat: 1) alasan perselisihan berkelanjutan terus menerus sebanyak 176.683 kasus, 2) alasan ekonomi sebanyak 71.194 kasus, 3) meninggalkan salah satu pihak 34.671 kasus, 4) alasan KDRT 3.271 kasus (Komnas Perempuan, 2021).

Gugatan perceraian dengan alasan KDRT semakin naik dari tahun ke tahun. Komisioner Komnas Perempuan, Indraswari, pada saat melansir 
Catahu Komnas Perempuan 2015 mengatakan bahwa tingginya angka kekerasan, terutama kekerasan dalam rumah tangga, yang dialami perempuan menjadi alasan utama maraknya gugatan cerai oleh pihak istri terhadap suami (Rahadian, 2015).

Pembatasan perceraian yang dilakukan Musa dan Tuhan Yesus seperti digambarkan di atas nampak lahir dalam konteks kondisi buruk yang dialami kaum perempuan dalam pernikahan. Keduanya bermaksud untuk memberikan jaminan kehidupan yang lebih adil bagi perempuan dalam pernikahan.

Dengan demikian, sebenarnya pembicaraan mengenai masalah perceraian dalam gereja mestinya tidak bisa dilepaskan dari konteks kehidupan perempuan di dalam rumah tangga. Salah satu masalah dalam kehidupan berumah tangga hingga di masa kini adalah kekerasan di mana perempuan cenderung menjadi korban. Selama penyebab gugatan cerai ini tidak ditangani oleh gereja dengan melihat masalah dari sisi korban (seperti dilakukan Musa dan Tuhan Yesus), maka potensi perceraian akan tetap tinggi.

Responden dalam penelitian ini sebagian besar adalah perempuan muda. Sebagian dari mereka, walaupun jumlahnya sedikit, tidak berani memastikan bahwa mereka tidak akan bercerai jika ada masalah dalam rumah tangga. Perempuan di masa kini dan di masa depan semakin terdidik dan mandiri. Didukung dengan gerakan perempuan yang terjadi secara global untuk memperjuangkan keadilan dan kesetaraan gender, 
mereka akan semakin berani menuntut kehidupan yang adil, termasuk dalam pernikahan. Konsep ketegaran hati yang dikemukakan Yesus perlu ditempatkan bukan hanya untuk menyalahkan pihak yang menggugat cerai, tetapi juga harus ditujukan kepada pihak yang mendorong terjadinya gugatan cerai.

\section{KESIMPULAN}

Dari penelitian ini nampak bahwa pengajaran gereja tentang pernikahan sangat kuat di kalangan jemaat. Pemahaman jemaat sejalan dengan pengajaran gereja. Hal ini tentu tidak lepas dari upaya gereja untuk terus melakukan pengajaran kepada jemaat melalui berbagai kegiatan pelayanan.

Namun demikian bagaimana pun juga potensi terjadinya perceraian tetap ada. Salah satu tantangan yang perlu diperhatikan dan direspon dengan serius dalam rangka memelihara keutuhan pernikahan umat adalah pergumulan kaum perempuan mengenai kekerasan dalam rumah tangga (KDRT). Data yang menunjukkan terus terjadinya pergerakan naik angka gugatan cerai karena alasan KDRT merupakan panggilan yang serius untuk ditanggapi.

Ulasan mengenai perceraian akan sulit menemukan solusi yang konkrit bila hanya didasarkan pada kajian biblika tanpa memperhitungkan konteks pernikahan riil di masa kini. Untuk itu penulis merekmondesikan penelitian lanjutan terhadap topik ini: 1) penelitian dengan melibatkan 
orang Kristen yang sudah melakukan perceraian untuk menemukan penyebab sesungguhnya, 2) penelitian dengan melibatkan para isteri di dalam jemaat.

\section{DAFTAR PUSTAKA}

Adiyanta, F. C. S. (2019). Hukum dan Studi Penelitian Empiris: Penggunaan Metode Survey sebagai Instrumen Penelitian Hukum Empiris. Administrative Law and Governance Journal, 2(4), 697-709. https://doi.org/10.14710/alj.v2i4.697-709

Andersen, R. (2019). What is Hardness of Heart and How Do You Get Rid of It? The Marriage Dance.

Burton, E. D. (1907). The Biblical Teaching concerning Divorce: II. New Testament Teaching. The Biblical World, 29(3), 191-200. https://doi.org/10.1086/473873

Coy, B. (2003). Hardness Of Hearts Leads To The Sin Of Divorce. South Florida, Sun Suntinel.

Davidson, R. M. (2011). Divorce and Remarriage in the Old Testament. 16(4).

Dias, N., Talaway, H., \& Hakubun, M. (2020). Perceraian dan Perzinahan: Tafsir Terhadap Feminis Matius 5: 27 - 32. Arumbae: Jurnal Ilmiah Teologi Dan Studi Agama, 2(1), 74-90. https://doi.org/10.37429/arumbae.v2i1.426

Douglas, J. D. (1996). Ensiklopedia Alkitab Masa Kini Jilid II M-Z. Yayasan Komunikasi Bina Kasih/OMF.

Gunawan, A. (2015). Hamba Tuhan dan Keluarganya. Jurnal Theologi Aletheia, 17(8), 9-12.

Harisantoso, I. T. (2019). Perceraian Warga GKJW Di Kabupaten Jember: Suatu Analisa Teori Pertukaran Sosial. Visio Dei: Jurnal Teologi Kristen, 59-78. https://doi.org/10.35909/visiodei.v1i1.5

Hutagalung, S., Bartholomeus, D. N., Hendrikks, A. C., Walukouw, Y. R., Hutabarat, R., Karosekali, E., Manurung, F., Sianipar, J. H., SImbolon, M., Hutabarat, M. S., \& Sagala, R. W. (2021). Konseling Pastoral. Yayasan Kita Menulis.

Jata, Y. F. S. (2019). Perkawinan Dalam Terang Kitab Suci. Atma Reksa : Jurnal Pastoral Dan Kateketik, 4(1), 1-10. 
Komnas Perempuan. (2021). CATAHU 2020 Komnas Perempuan: Lembar Fakta dan Poin Kunci . Komnas Perempuan. https://komnasperempuan.go.id/siaran-pers-detail/catahu-2020komnas-perempuan-lembar-fakta-dan-poin-kunci-5-maret-2021

Lodewyck, J. (2019). Sikap Etis Kristen Terhadap Perceraian Menurut Markus 10:9. Missio Ecclesiae, 8(2), 155-171. https://doi.org/10.52157/me.v8i2.102

Maiaweng, P. C. D. (2017). Perceraian dan Pernikahan Kembali. Jurnal Jaffray, 15(1), 97-114. https://doi.org/10.25278/jj71.v15i1.237

Matondang, A. (2014). Faktor-faktor yang Menyebabkan Perceraian dalam Perkawinan. Jurnal IImu Pemerintahan Dan Sosial Politik UMA, 2(2), 141-150.

Muller, E. (n.d.). Jesus and Divorce and Remarriage in Matthew 19. Biblical Research Institute General Conference of Seventh-Day Adventists ${ }^{\circledR}, 6$.

Musyafah, A. A. (2020). Perkawinan Dalam Perspektif Filosofis Hukum Islam. Crepido, 2(2), 111-122. https://doi.org/10.14710/crepido.2.2.111-122

Putra, A. (2020). Problematika Teks dan Makna Matius 19: 9. Missio Ecclesiae, 9(2), 1-16. https://doi.org/10.52157/me.v9i2.122

Rahadian, L. (2015). Kekerasan Perempuan Sebabkan Angka Perceraian Membludak. CNN Indonesia.

https://www.cnnindonesia.com/nasional/20150306152900-20-

37272/kekerasan-perempuan-sebabkan-angka-perceraianmembludak

Roos, A. (2006). Questions About Marriage And Divorce (Matthew 19:312). Bible.Org.

Rusli. (2019). Perceraian Dalam Perjanjian Lama Dan Implikasinya Dalam Kehidupan Kekristenan Masa Kini. Geneva: Jurnal Teologi Dan Misi, 17(1), 108-114.

Sirait, P. H. N. (2020). Sampai Maut Memisahkan kita?(Tafsir Matius 19: 3-12 Diperhadapkan dengan Keberpihakan Gereja Terhadap Istri Korban KDRT). Jurnal Teologi Cultivation, 4(2), 132-151. https://doi.org/10.46965/jtc.v4i2.320

Stevanus, K. (2018). Sikap Etis Gereja Terhadap Perceraian dan Pernikahan Kembali. Jurnal Kurios, Volume 4(2), 135-156. https://doi.org/10.30995/kur.v4i2.80

Sugiyono. (2013). Metode Penelitian Kuantitatif, Kualitatif dan $R \& D$. Alfabeta. 
Surbakti, P. H. (2020). Jangan Menceraikan Istri yang Berzinah: Penafsiran terhadap Matius 19:9. Evangelikal: Jurnal Teologi Injili Dan $\begin{array}{llll}\text { Pembinaan Warga Jemaat, } & \text { 4(1), }\end{array}$ https://doi.org/10.46445/ejti.v4i1.191

Suryani, E. (2018). Tingkat Perceraian Muslim dan Non muslim Di Indonesia. Mizan: Journal of Islamic Law, 3(2), 153-200. https://doi.org/10.32507/mizan.v3i2.162

Suryaningrum, N. (2019). Determinan Perceraian di Jakarta Timur Tahun 2014 (Studi Data Pengadilan Agama dan Pengadilan Negeri). Forum IImu Sosial, 46(2), 128-141. https://doi.org/10.15294/fis.v46i2.19627 